\title{
KEBIJAKAN PENGEMBANGAN PARIWISATA BERKELANJUTAN: KAJIAN TEORETIS DAN EMPIRIS
}

\author{
Dewa Ayu Diyah Sri Widari \\ Akademi Pariwisata Denpasar \\ Email: dewaayusriwidari@gmail.com
}

Received: June 5, 2020 | Accepted: June 24, 2020 | Published: Nov. 2, 2020

Permalink/DOI: https://doi.org/10.53356/diparojs.v1i1.12

\begin{abstract}
ABSTRAK
Pentingnya peran industri pariwisata bagi perekonomian mendorong negara untuk mengembangkan sektor pariwisata, namun menghadapi tantangan dalam perkembangannya. Penelitian ini bertujuan untuk mengkaji kebijakan pembangunan berkelanjutan dan implementasi kebijakan pariwisata berkelanjutan terhadap aspek ekonomi, sosial budaya, dan lingkungan. Metode pengumpulan data melalui studi dokumen. Perubahan pola wisatawan, perubahan psikografi pelancong mempengaruhi model pengembangan pariwisata. Pembangunan pariwisata berkelanjutan merupakan upaya untuk dapat menghadapi kompetisi global dan nasional. Kebijakan pariwisata berperan penting dalam pengembangan pariwisata berkelanjutan, pelaksanaannya tergantung pada dukungan pemerintah pusat, pemerintah daerah, industri, dan masyarakat. Sementara pariwisata berkelanjutan penting, pertumbuhan ekonomi masih merupakan aspek penting dari pemerintah di beberapa negara berkembang.
\end{abstract}

Kata kunci: pariwisata berkelanjutan, kebijakan pariwisata, implementasi.

\begin{abstract}
The importance of the role of tourism industry for the economy encourages a country to develop the tourism sector, but also face challenges in its development. This research aims to assess the policy of sustainable development and the implementation of sustainability tourism policy of economic, socio-cultural, and environmental aspects. The method of collecting data through document study. Changes in travelers' pattern, changes of travelers' psychography influence the tourism development model. Sustainable tourism development is an effort to be able to face global and national competitions. Tourism policy plays an important role in the development of sustainable tourism, its implementation depending on the support of the central government, local government, industry, and the community. While sustainable tourism is important, economic growth is still a vital aspect of the government in some developing countries.
\end{abstract}

Key words: sustainable tourism, tourism policy, implementation 


\section{PENDAHULUAN}

Sektor pariwisata berperan penting dalam menunjang perekonomian, hal ini membuat negara penerima wisatawan berlombalomba untuk mengembangkan industri pariwisata. Berbagai upaya dilakukan agar destinasi wisata menjadi menarik dan mampu menghasilkan jumlah kunjungan wisatawan sebanyak-banyaknya. Berdasarkan data dari World Economic Forum (2017), pariwisata menyediakan sekitar $10 \%$ dari pendapatan dunia dan mempekerjakan hampir sepersepuluh dari tenaga kerja di dunia. Semua berdasarkan dampak ekonomi pariwisata aktual dan potensial. Banyak orang menekankan aspek-aspek positif pariwisata sebagai sumber devisa, sebagai upaya untuk menyeimbangkan perdagangan luar negeri. Dengan ramalan 1,8 milyar wisatawan internasional 2030, industri pariwisata memiliki potensi untuk memainkan peran kunci dalam menciptakan kesempatan kerja berkualitas tinggi, bertindak sebagai kendaraan untuk melindungi dan memulihkan keanekaragaman hayati bumi dan membantu membangun jembatan antara orang-orang dan budaya. Penelitian menunjukkan bahwa untuk setiap 30 wisatawan baru yang datang ke suatu destinasi, satu pekerjaan baru diciptakan.

Pentingnya peranan industri pariwisata bagi perekonomian mendorong suatu negara mengembangkan sektor pariwisata, namun di sisi lain juga menghadapi tantangan dalam pengembangannya. Sesuai dengan pernyataan Edgel et al. (2008) industri pariwisata global menghadapi banyak kekhawatiran beberapa dekade mendatang, serta cukup jelas bahwa kebijakan pariwisata dan perencanaan strategis melalui banyak dinamika di masa depan. Memang perlu untuk melihat fokus global yang lebih besar dari industri pariwisata yang potensial untuk pertumbuhan. Namun bersamaan dengan itu, manfaat keberlanjutan pariwisata bagi masyarakat lokal terus bertumbuh dalam prioritas dan kepentingan.
Konsep keberlanjutan sebagai pengembangan sumber daya dan filosofi manajemen menyerap semua tingkat kebijakan dan praktik yang berkaitan dengan pariwisata, dari tingkat lokal sampai global. Melalui pariwisata berkelanjutan, manajemen lingkungan alam dan fisik harus hidup berdampingan dengan ekonomi, sosial budaya, keselamatan dan keamanan penduduk lokal dan bangsa. Menjaga keseimbangan antara pertumbuhan ekonomi dan melindungi sumber daya alam merupakan tantangan bagi pemerintah, masyarakat, dan industri untuk bekerjasama dalam pengembangan pariwisata berkelanjutan. Edgel et al. (2008:186) menyebutkan bahwa bertambah luasnya tantangan kerjasama antara anggota komunitas pariwisata untuk mendukung pariwisata yang berkelanjutan juga menjadi tantangan ke depan. Konsep pariwisata berkelanjutan menggunakan pengembangan pariwisata berkelanjutan sebagai stimulator ekonomi untuk mencapai pertumbuhan dengan tetap menjaga lingkungan alami mendapat perhatian yang lebih besar dan muncul secara bersamaan dari industri, pemerintahan maupun akademik.

Isu keberlanjutan yang pada awalnya dibatasi pada lingkungan alam, saat ini berkembang meliputi aspek sosial, ekonomi, dan budaya. Sekarang ini pemerintah, lembaga internasional, asosiasi bisnis, institusi akademik dan lembaga swadaya masyarakat mengakui bahwa tanpa pertimbangan keberlanjutan, tidak ada usaha pembangunan yang bermanfaat bagi seluruh pemangku kepentingan. Pembangunan berkelanjutan menjadi sangat relevan dalam pengembangan kepariwisataan karena produk pariwisata hampir selalu berupa alam atau budaya masyarakat. Sektor pariwisata sangat berkepentingan pada pelestarian sumber daya alam dan sumber daya budaya sebagai produk wisata yang dijual kepada wisatawan. Dengan demikian, diperlukan pemahaman terhadap nilai-nilai dalam 
kepariwisataan yang terdapat di suatu destinasi agar dapat dibuatkan kebijakan dan manajemen pembangunan kepariwisataan.

Tujuan penelitian ini adalah untuk mengkaji kebijakan pengembangan pariwisata berkelanjutan, dan mengkaji implementasi kebijakan pariwisata berkelanjutan dari aspek ekonomi, sosial budaya, dan lingkungan.

\section{KAJIAN LITERATUR}

\subsection{Pariwisata Berkelanjutan}

Pariwisata berkelanjutan telah menjadi isu yang menjadi perhatian dalam perencanaan destinasi dan kebijakan regional dan nasional selama beberapa waktu. Perhatian ini menghasilkan berbagai metode yang berbeda dalam memandang keberlanjutan dalam industri pariwisata. Dalam beberapa tahun terakhir, ada banyak buku yang diproduksi berkaitan dengan pariwisata berkelanjutan yang tersedia dalam 25 tahun sebelumnya. Ada puluhan konferensi di seluruh dunia setiap tahun, dengan pariwisata berkelanjutan sebagai tema sentral (Edgel et al., 2008: 332). World Tourism Organization (WTO) merumuskan Global Code of Ethics for Tourism yang menekankan upaya untuk memasyarakatkan pengembangan pariwisata yang berkelanjutan dan bertanggungjawab yang dapat bermanfaat untuk seluruh masyarakat. Pengembangan pariwisata yang berkelanjutan mempunyai 12 tujuan, yaitu; (a) kelayakan secara ekonomi; (b) kemakmuran suatu wilayah; (c) lapangan kerja yang berkualitas; (d) kesetaraan sosial; (e) pemenuhan hak wisatawan; (f) kendali oleh masyarakat lokal; (g) kesejahteraan komunitas; (h) kekayaan budaya; (i) Integritas destinasi secara fisik; (j) keberagaman biologis; (k) efisiensi sumber daya; dan (l) kemurnian lingkungan. Pengembangan pariwisata yang berkelanjutan dilaksanakan berdasarkan tiga prinsip utama yaitu perlindungan lingkungan, tanggungjawab terhadap masyarakat, dan kesehatan

perekonomian

(http://www.docstoc.com/docs/).

Meskipun perhatian global telah difokuskan pada pariwisata berkelanjutan dan dampak pariwisata massal, definisi dan operasionalisasi pariwisata berkelanjutan menjadi tugas yang berat, dengan interpretasi yang berbeda dari berbagai cendekiawan dan organisasi internasional (Berno dan Bricker, 2001). Misalnya, konsep pariwisata berkelanjutan, menurut PBB didefinisikan sebagai kegiatan wisatawan yang menghasilkan pengelolaan sumber daya yang efisien dalam mencapai kebutuhan ekonomi, sosial dan estetika dan serta merta menjaga integritas sistem budaya, proses ekologi dan keanekaragaman hayati yang esential serta sistem kehidupan pendukung (UNEP dan WTO, 2005). Selain itu, Lankford dan Lankford (2000) menyatakan bahwa untuk memastikan realisasi pariwisata berkelanjutan, harus ada suatu kondisi tertentu yakni partisipasi masyarakat selaku tuan rumah dalam proses perencanaan, pembangunan dan manajemen, pendidikan untuk wisatawan dan masyarakat lokal tentang pengembangan pariwisata, memahami dan menghormati perlindungan habitat satwa liar, efisiensi energi dan iklim mikro, serta investasi mode transportasi alternatif yang ramah lingkungan. Sedangkan WTO (1998) mengkonseptualisasikan pariwisata berkelanjutan sebagai salah satu upaya untuk memenuhi kebutuhan para wisatawan yang hadir dan daerah tuan rumah sembari melindungi dan meningkatkan peluang untuk masa depan pembangunan pariwisata. Konsep WTO dikaitkan dengan manajemen oleh Edgel, et al. (2008) bahwa konsep keberlanjutan sebagai pengembangan sumber daya dan filosofi manajemen menyerap semua tingkat kebijakan dan praktik yang berkaitan dengan pariwisata, dari lokal ke global. Melalui pariwisata berkelanjutan, manajemen lingkungan fisik dan alam harus hidup berdampingan 
dengan ekonomi, sosial budaya, penduduk lokal dan bangsa.

Pariwisata berkelanjutan diperlukan dalam pengembangan destinasi. Dalam rencana dan visi strategis, penting untuk memahami dinamika perubahan sosial dan perkembangan di destinasi. Ada perdebatan terus-menerus yang berkaitan dengan nilai pendekatan siklus hidup sebagai teknik analisis untuk pengelolaan destinasi. Melalui pengelolaan yang hati-hati, pariwisata berkelanjutan dapat dicapai oleh destinasi pada setiap tahap siklus hidup. Butler (1992) berpendapat bahwa perspektif jangka panjang memberikan kontrol dan tanggung jawab untuk mencegah agar destinasi tidak melebihi kapasitas dan penurunan kunjungan yang tak terelakkan. Pandangan ini didukung oleh Bramwell dan Lane (1993) yang mengidentifikasi elemen kunci keberlanjutan sebagai gagasan pembentukan perencanaan dan strategi yang holistik.

\subsection{Kebijakan Pariwisata Berkelanjutan}

Kebijakan pariwisata merupakan sarana lokal, regional, nasional dan supranasional lembaga dan organisasi mencapai tujuan dalam pengembangan pariwisata. Ada dua jenis kebijakan pariwisata: kebijakan pariwisata fundamental dan tambahan. Kebijakan pariwisata dapat berada pada tingkatan makro dan mikro (Vucetic, 2008). Kebijakan pariwisata kompleks, dengan cepat berubah dan berpengaruh besar pada lingkungan. Dapat dikatakan menjadi bergolak, kompetitif dan dinamis (Stevenson et al., 2008).

Kebijakan pariwisata berkelanjutan dalam dunia sekarang ini adalah positif, pendekatan yang berusaha untuk menjaga kualitas produk wisata selama periode waktu berkelanjutan untuk memenuhi pertumbuhan pasar domestik dan internasional bagi pengalaman wisata yang berwawasan. Manusia memiliki kemampuan untuk memanipulasi dan memodifikasi aspek-aspek tertentu dari lingkungan menjadi lebih baik atau buruk, oleh karena itu tanpa formula kebijakan yang hati-hati dan alat manajemen yang dimanfaatkan, pariwisata dapat menyebabkan degradasi lingkungan dan mengurangi atribut untuk digunakan oleh generasi mendatang (Edgel et al., 2008:192). Di sisi lain Goldner dan Ritchie (2006:405) menguraikan kebijakan pariwisata merupakan suatu bentuk regulasi, aturan, pedoman, arah, dan sasaran pembangunan serta strategi yang memberikan kerangka dalam pengambilan keputusan individu maupun kolektif yang secara langsung mempengaruhi pengembangan pariwisata dalam jangka waktu tertentu dan sekaligus pengaturan atau ketentuan terhadap kegiatan operasional yang berlangsung di suatu destinasi.

Menurut Dowling dan Fennell (2003) dalam menentukan kebijakan nasional dan regional, matriks semua sektor aktivitas dinilai dan dievaluasi meliputi: dampak positif dan negatif ekonomi, sosial, dan lingkungan. Dengan demikian pariwisata dan faktor sumberdaya lingkungan tidak diisolasi dalam pembuatan keputusan. Selain itu, Airey dan Chong (2011) juga menunjukkan bahwa bekerja pada kebijakan terkait dengan masalah, keprihatinan dan kesempatan yang diciptakan oleh pariwisata, seperti peningkatan lalu lintas udara dan degradasi lingkungan serta masalah-masalah perlindungan konsumen membutuhkan respon kebijakan pemerintah. Dalam konteks ini misalnya, hubungan kebijakan pariwisata dengan keberlanjutan dan perubahan iklim mendapat banyak perhatian (Coles et al., 2013).

Kebanyakan pengulas percaya bahwa sektor publik memiliki peran lebih besar dalam pengembangan bentuk-bentuk pariwisata berkelanjutan (Swarbrooke, 1999). Ada sejumlah alasan mengapa sektor publik harus memainkan peran utama dalam berusaha mengembangkan bentuk-bentuk pariwisata berkelanjutan (Swarbrooke, 1999) yaitu: 
a. Sektor publik biasanya memiliki mandat untuk mewakili seluruh populasi kelompok-kelompok kepentingan, tidak hanya kelompok tertentu atau pemegang saham.

b. Sektor publik terlihat tidak memihak dengan tidak komersial atau tertarik untuk melindungi.

c. Karena tidak dibatasi oleh tujuan-tujuan keuangan jangka pendek, sektor publik dipandang mampu untuk mengambil pandangan jangka panjang.

Sektor publik mempengaruhi pariwisata dalam beberapa cara, dan dapat berperan dalam pengembangan pariwisata berkelanjutan termasuk undang-undang dan peraturan, pendanaan dan fiskal penggunaan lahan insentif, perencanaan, pembangunan dan kontrol bangunan, termasuk peran penilaian dampak lingkungan, penyediaan infrastruktur dan suprastruktur (Swarbrooke, 1999). Tetapi hal ini hampir bermasalah di negara-negara berkembang. Karena prinsip-prinsip pengembangan pariwisata berkelanjutan tampaknya telah ditetapkan oleh negara berkembang tanpa memperhitungkan kondisi perkembangan dunia (Tosun, 2001).

Dalam konteks penguatan konsep sustainability pada pengelolaan aktivitas usaha, Kotler (1997) menekankan strategi untuk memperhatikan stakeholder seperti karyawan, pemerintah, supplier, dan lingkungan. Kotler menegaskan agar perilaku prososial perusahaan diwujudkan melalui pengelolaan lingkungan, kesehatan, pendidikan dan produk organik atau ekologis. Hal ini perlu didukung dengan perilaku prososial konsumen antara lain memperhatikan dampak produk yang dikonsumsi, penghematan energi, melakukan daur ulang, membeli produk organik dan memanfaatkannya secara cerdas dan bijak. Dalam pandangan Page (2007), prinsip dasar yang harus dijadikan acuan dalam penyusunan kebijakan pengembangan destinasi pari- wisata yaitu mencakup dimensi posisi kapasitas masyarakat, lingkungan, pelibatan masyarakat, dan pertimbangan politik pembangunan.

\section{METODE PENELITIAN}

Penulisan artikel ini menggunakan metode pengumpulan data melalui studi dokumen. Studi dokumen merupakan suatu teknik pengumpulan data melalui penggunaan referensi dari buku-buku untuk memperoleh pendapat, teori, hasil penelitian yang berhubungan dengan masalah penelitian. Studi dokumen dilakukan untuk menggali teori-teori dasar, konsep-konsep, dan hasil penelitian yang relevan untuk memperoleh orientasi yang lebih luas mengenai topik penelitian.

\section{PEMBAHASAN}

\subsection{Implementasi Kebijakan Pariwisata Berkelanjutan}

Dalam konteks pembangunan kepariwisataan di Indonesia, adopsi etos dan prinsip pembangunan kepariwisataan yang berkelanjutan diamanatkan oleh Undang-undang dan Rencana Strategik Pembangunan Kepariwisataan Nasional. Undang-undang Republik Indonesia Nomor 10 Tahun 2009 tentang Kepariwisataan menyebutkan bahwa penyelenggaraan kepariwisataan di Indonesia berdasarkan azas yang sejalan dengan etos dan prinsip pembangunan kepariwisataan yang berkelanjutan. Bab II Pasal 2 UU No. 10 Tahun 2009 menyebutkan bahwa azas penyelenggaraan kepariwisataan di Indonesia adalah manfaat, kekeluargaan, adil dan merata, keseimbangan, kemandirian, kelestarian, partisipatif, berkelanjutan, demokratis, kesetaraan, dan kesatuan. Lebih lanjut Pasal 5 UU No. 10 Tahun 2009 juga mengamanatkan bahwa penyelenggaraan kepariwisataan di Indonesia harus berprinsip pada aspek-aspek yang di dalamnya mencakup etos dan prinsip keberlanjutan. 
Bali sebagai salah satu destinasi utama di Indonesia mengembangkan Kepariwisataan Budaya Bali yaitu kepariwisataan Bali yang berlandaskan Kebudayaan Bali yang dijiwai oleh ajaran Agama Hindu dan falsafah tri hita karana sebagai potensi utama dengan menggunakan kepariwisataan sebagai wahana aktualisasinya. Terwujud hubungan timbalbalik yang dinamis antara kepariwisataan dan kebudayaan yang membuat keduanya berkembang secara sinergis, harmonis dan berkelanjutan untuk dapat memberikan kesejahteraan kepada masyarakat, kelestarian budaya dan lingkungan (Peraturan Daerah Provinsi Bali Nomor 2 Tahun 2012 tentang Kepariwisataan Budaya Bali). Pengembangan pariwisata ditujukan agar potensi yang dimiliki dapat dimanfaatkan untuk pariwisata dan berkembangnya pariwisata diharapkan memberi manfaat terhadap destinasi pariwisata dan masyarakat lokal.

Pengembangan pariwisata yang berkelanjutan dilaksanakan berdasarkan tiga prinsip utama yaitu perlindungan lingkungan (environment protection), tanggung jawab terhadap masyarakat (social responsibility), dan kesehatan perekonomian. Prinsip pengembangan pariwisata berkelanjutan sejalan dengan filosofi Subak Jatilwih. Menurut Parimartha (2008) secara filosofis, sistem Subak Jatiluwih sebagai bentuk warisan budaya Bali memiliki nilai dalam arti membangun kesetaraan, perpaduan antara potensi budaya (kreativitas masyarakat) dan lingkungan alam (landscape). Juga hubungan yang harmonis dengan kekuasaan Tuhan (Ida Hyang Widhi) terus dipertahankan, dipandu dengan konsep tatwa Tri Hita Karana. Pernyataan tersebut dipertegas lagi setelah penetapan Subak Jatiluwih sebaga Warisan Budaya Dunia tahun 2012.

Jatiluwih ditetapkan sebagai desa wisata pada tahun 1992, sebagai daya tarik wisata di Kabupaten Tabanan sejak tahun 2008. Dalam perkembangan selanjutnya, terasering sawah di Desa Wisata Jatiluwih oleh UNESCO ditetapkan sebagai Cultural Landscape of Bali Province: the Subak System as a Manifestation of the Tri Hita Karana Philosophy pada tanggal 29 Juni 2012. Yamashita (2013) menyebutkan penetapan subak sebagai Warisan Budaya Dunia menurut UNESCO karena subak sebagai warisan budaya dunia merupakan kombinasi antara alam dan hasil karya manusia, dalam perkembangannya harus memberikan manfaat bagi pelestarian alam serta keberhasilan dari aspek sosial, ekonomi, dan sumberdaya budaya. Berkaitan dengan status yang diberikan, terdapat beberapa kebijakan yang ditetapkan untuk mengatur pengembangan Desa Jatiluwih untuk mendukung pariwisata berkelanjutan, yaitu:

a. Peraturan Bupati Tabanan Nomor 27 Tahun 2011 tentang Penetapan Sawah Berkelanjutan Sebagai Sawah Abadi Pada Subak Di Kecamatan Penebel Kabupaten Tabanan.

b. Surat Edaran Nomor 050/0221/Bappeda perihal Pengendalian Pembangunan Pada Kawasan Warisan Budaya Dunia Jatiluwih.

c. Keputusan Manajer Operasional Daya Tarik Wisata Jatiluwih Nomor 03 Tahun 2017 tentang Susunan, Uraian Tugas, dan Upah Tenaga Kerja Pengelola Bank Sampah "Green Village" di Daya Tarik Wisata Jatiluwih.

Apabila dikaitkan dengan definisi dari PBB mengenai pariwisata berkelanjutan yaitu kegiatan wisatawan yang menghasilkan pengelolaan sumber daya yang efisien dalam mencapai kebutuhan ekonomi, sosial dan estetika dan serta menjaga integritas sistem budaya, proses ekologi dan keanekaragaman hayati yang esential serta sistem kehidupan pendukung. Konsep pariwisata berkelanjutan dari PBB sesuai dengan hasil penelitian Widari (2015) yang dilakukan di Desa Jati- 
luwih. Masyarakat Desa Jatiluwih mendapatkan manfaat dari penyerapan tenaga kerja dan kesempatan membuka usaha-usaha pariwisata seperti restoran, homestay, stand kuliner, selain itu juga mendapatkan distribusi dari pengelolaan daya tarik wisata. Masyarakat mendapatkan manfaat dari pengembangan pariwisata, hal ini merupakan bagian dari pengembangan pariwisata berkelanjutan dari aspek keberlanjutan ekonomi. Dari aspek sosial budaya, ditemukan bahwa budaya pertanian yang diterapkan oleh warga subak terus dilaksanakan sebagai suatu kebiasaan (tradisi). Selain upacara yang berkaitan dengan aktivitas petani di sawah, sistem tanam padi juga terus diterapkan oleh warga subak. Subak Jatiluwih membagi sistem tanam padi menjadi dua periode. Periode pertama, penanaman padi Bali (lokal) dan periode kedua, penanaman padi varietas (serang, mangsur, sigelis, PB dan IR).

Masyarakat Desa Jatiluwih terus menyelenggarakan upacara yang berkaitan dengan aktivitas pertanian sebagai sebuah tradisi. Sistem tanam padi juga terus diterapkan oleh warga subak. Sebagai masyarakat petani yang menganut pola hidup agraris relegius, upaya-upaya yang dilakukan dengan terus menyelenggarakan upacara yang berkaitan dengan aktivitas pertanian dan tetap menerapkan tradisi sistem tanam padi, merupakan suatu wujud implementasi pariwisata berkelanjutan dari aspek sosial budaya. Namun, terjadinya pergeseran pola tanam padi dengan menggunakan traktor untuk membajak sawah, hal ini kurang sesuai dengan konsep pariwisata berkelanjutan. Terlebih lagi dengan penetapan Subak Jatiluwih sebagai bagian dari Warisan Budaya Dunia, seharusnya penggunaan traktor untuk membajak sawah dikurangi. Wisatawan yang datang ke Desa Jatiluwih, selain ingin menyaksikan keindahan terasering sawah dengan sistem subaknya, mereka juga ingin menyaksikan budaya tradisional masyarakat, salah satu diantaranya yaitu membajak sawah menggunakan sapi.

Peningkatan jumlah kunjungan wisatawan setelah penetapan subak sebagai bagian dari Warisan Budaya Dunia, berimplikasi pada peningkatan fasilitas pariwisata yang diperlukan. Kondisi ini menyebabkan terjadinya peningkatan pembangunan fasilitas restoran dan rumah makan yang tidak sesuai dengan aturan tata ruang. Maraknya alih fungsi lahan pertanian baik untuk pembangunan perumahan maupun pembangunan fasilitas pariwisata, Pemerintah Kabupaten Tabanan mengeluarkan beberapa kebijakan yaitu (1) Peraturan Bupati Tabanan Nomor 27 Tahun 2011 tentang Penetapan Sawah Berkelanjutan Sebagai Sawah Abadi Pada Subak Di Kecamatan Penebel Kabupaten Tabanan, (2) Surat Edaran Nomor 050/0221/Bappeda perihal Pengendalian Pembangunan Pada Kawasan Warisan Budaya Dunia Jatiluwih. Kebijakan yang dikeluarkan oleh Pemerintah Kabupaten Tabanan dalam implementasinya menghadapi beberapa kendala. Pengelolaan Daya Tarik Wisata Jatiluwih memberi peluang bagi masyarakat lokal untuk membuka usaha pariwisata seperti restoran. Namun, usaha restoran dibangun pada lahan yang menjadi bagian dari kawasan Warisan Budaya Dunia. Selain itu kebutuhan fasilitas parkir kendaraan juga semakin meningkat. Fasilitas parkir juga dibangun pada lahan yang menjadi bagian dari Warisan Budaya Dunia. Kondisi ini menimbulkan pro dan kontra di kalangan masyarakat lokal. Jatiluwih dihadapkan pada dilema antara status sebagai daya tarik wisata yang memerlukan fasilitas pariwisata, dengan status sebagai Warisan Budaya Dunia yang keberadaannya harus dilestarikan. Sesuai dengan pernyataan Edson (2004) menyebutkan industri warisan menimbulkan konflik antara pelestarian warisan dan pengembangan pariwisata. Hal ini didukung oleh pernyataan 
McMorran (2008) bahwa dengan meningkatnya popularitas pariwisata warisan, pemerintah, masyarakat dan pengusaha perseorangan mengeksploitasi situs warisan untuk tujuan ekonomi.

Penelitian lain mengenai implementasi kebijakan pada warisan budaya yaitu penelitian yang dilakukan oleh DuCros, et al. (2005). Studi yang mempelajari dua contoh yaitu Hutong di kotamadya Beijing dan bagian dari Great Wall di Huanghua. Hasil penelitiannya memaparkan bahwa konservasi warisan perkotaan dan komodifikasi produk wisata pada persimpangan jalan di Cina. Banyak konflik yang disaksikan dalam studi kasus, timbul dari kurang jelasnya desain untuk mengintegrasikan konservasi warisan dalam penggunaan tanah dan pengembangan perencanaan dan kurangnya kepemimpinan yang kuat secara individu atau organisasi untuk bertindak sebagai fasilitator. Dua pilihan juga dicatat untuk komodifikasi dan konservasi potensi daya tarik wisata. Salah satunya adalah pengerasan situs dan membangun kembali pada bagian Badaling Great Wall, dikembangkan untuk menahan tekanan kunjungan dari pariwisata massal domestik dan internasional. Pilihan lain adalah menetapkan beberapa atraksi, seperti Huanghua, sebagai produk niche masa depan. Produk ini kemudian dipasarkan dan dilestarikan untuk jumlah wisatawan yang dibatasi, terdiri dari pengunjung dengan perjalanan secara independen, dan sebagai bagian dari paket wisata inklusif.

Pariwisata berkelanjutan berkaitan dengan kebijakan publik, sesuai dengan hasil penelitian Cetinel dan Yolal (2009). Penelitian ini mengungkapkan sebuah analisa teoritis dari kebijakan publik dan pariwisata berkelanjutan di Turki, dipaparkan bahwa Turki adalah salah satu negara terbesar di Eropa dan Timur Tengah dengan luas kurang lebih $800.000 \mathrm{~km}^{2}$. Hal ini berimplikasi ter- hadap sulitnya untuk mengatur industri pariwisata di tanah yang luas karena berbeda prioritas dan kebutuhan dari setiap daerah dan destinasi. Perubahan radikal dan demokratisasi negeri dan struktur politik diperlukan untuk manajemen yang lebih baik dari sumber daya dan industri pariwisata. Hal ini harus diikuti dengan pendekatan perencanaan daerah, yang memerlukan desentralisasi kekuasaan pemerintah pusat untuk regional dan pihak berwenang setempat. Berfokus pada kualitas daripada kuantitas dapat mengurangi dampak negatif pariwisata tanpa mengorbankan manfaat ekonomi yang diharapkan.

Penelitian lain dilakukan oleh $\mathrm{Xu}$ dan Sofield (2013) mengungkapkan bahwa sesuai dengan prinsip-prinsip keberlanjutan, penggunaan energi yang rendah, memproteksi lingkungan, dan penggunaan sumber daya yang rasional dapat menciptakan pengembangan pariwisata berkelanjutan. Kebijakan terhadap polusi lingkungan dari kegiatan pariwisata diatur dalam tiga kebijakan yaitu Beijing tahun 2001, Chongqing tahun 2005, dan Guizhou tahun 2002. Kebijakan pariwisata secara signifikan dipengaruhi oleh pengelolaan pariwisata di tingkat nasional maupun daerah, walaupun kebijakan tersebut diformulasikan oleh orang-orang pemerintahan secara keseluruhan. Kesuksesan dalam memenangkan kompetisi sumber daya dari pemerintah pusat dalam pengembangan kepariwisataan ditentukan oleh pemerintah pusat. Walaupun keberlanjutan menjadi hal yang sangat penting dalam masyarakat China, pertumbuhan ekonomi masih merupakan hal yang sangat vital dalam sistem pemerintahan di Cina.

Implementasi pariwisata berkelanjutan seringkali dihadapkan pada kurangnya sumberdaya, yang berimplikasi pada kebijakan yang diterapkan pada destinasi. Penelitian yang dilakukan oleh Akama (2004). Studi kasus Kenya menunjukkan, biaya berskala untuk 
investasi awal, modal proyek pariwisata intensif terlalu tinggi untuk pemerintah Afrika dan investor adat sehingga harus bergantung pada investasi modal eksternal terutama dari konglomerat multinasional. Dengan realisasi pentingnya pengembangan pariwisata dalam menghasilkan banyak valuta asing, pemerintah Kenya berpaling kepada investor asing dan multinasional dalam menyediakan modal awal untuk pembentukan dan pengembangan fasilitas pariwisata. Dalam hal ini, pemerintah mengadopsi kebijakan pintu terbuka terhadap investor pariwisata multinasional dan pengembang. Inisiatif kebijakan pemerintah yang mempromosikan pengembangan skala besar, proyek-proyek pariwisata padat modal cenderung menghalangi investasi adat dan lokal di sektor pariwisata. Jadi, sementara orang-orang lokal menanggung sebagian besar biaya langsung dan tidak langsung dari konservasi satwa liar dan pengembangan pariwisata, mereka menerima pendapatan yang minimal dan manfaat yang tidak signifikan dari sektor pariwisata.

\section{PENUTUP}

Pengembangan pariwisata dapat memberikan manfaat terkait dengan peningkatan devisa, memperkuat neraca perdagangan, peningkatan perekonomian, berkembanganya kesenian dan budaya masyarakat lokal, pelestarian lingkungan, dan manfaat lainnya. Namun di sisi lain, pengembangan industri pariwisata juga menghadapi berbagai tantangan. Perubahan pola perjalanan wisatawan, perubahan psikografi wisatawan memberi pengaruh pada model pengembangan pariwisata. Pengembangan pariwisata berkelanjutan menjadi upaya untuk dapat menghadapi kompetisi global dan nasional. Meskipun perhatian global telah difokuskan pada pariwisata berkelanjutan dan dampak pariwisata massal, definisi dan operasionalisasi pariwisata berke- lanjutan menjadi tugas yang berat, dengan interpretasi yang berbeda dari berbagai cendekiawan dan organisasi internasional. Kebijakan pariwisata berkelanjutan dalam dunia sekarang ini adalah positif, pendekatan yang berusaha untuk menjaga kualitas produk wisata selama periode waktu berkelanjutan untuk memenuhi pertumbuhan pasar domestik dan internasional bagi pengalaman wisata.

Implementasi konsep holistik pembangunan pariwisata berkelanjutan di destinasi menjadi sebuah tantangan. Meningkatnya popularitas suatu destinasi wisata berimplikasi terhadap eksploitasi sumber daya yang dimiliki untuk tujuan ekonomi. Walaupun keberlanjutan menjadi hal yang sangat penting, pertumbuhan ekonomi masih merupakan hal yang sangat vital dalam sistem pemerintahan di beberapa negara berkembang. Kebijakan pariwisata memegang peranan penting dalam pengembangan pariwisata berkelanjutan dan implementasinya tergantung pada dukungan dari pemerintah pusat, pemerintah lokal, industri, dan masyarakat.

\section{DAFTAR PUSTAKA}

Airey, D., dan Chong, K. 2010. "National Policy Makers for Tourism in China". Annals of Tourism Research, 37(2), 295-314. [diakses 2 September 2019]. tersedia pada: http:dx.doi.org/10.1016/j.annals.2009.09.004

Akama, J.S. 2004. Neocolonialism, Dependency and External Control of Africa's Tourism Industry: A Case Study of Wildlife Safari Tourism in Kenya. dalam Tourism and Poscolonialism: Contested, Discourse, Identities and Representations. Hall, M.C and Tucker, $\mathrm{H}$ (eds). London and New York: Routledge.

Berno, T., dan Bricker, K. 2001. "Sustainable Tourism Development: the Long Road from Theory to Practice". International Journal of Economic Development 3 (3), 1-18. [diakses 19 Sepetember 2019]. tersedia pada: http:dx.doi.org/10.15181/rfds.v14i3.873. 
Bramwell, W and Lane, B. 1993. "Sustainable Tourism: An Evolving Global Approach". Journal of Sustainable Tourism. 1(1), 1-5. [diakses 19 September 2019]. tersedia pada: http:dx.doi.org/10.1080/09669589309450696

Butler, R. 1992. Alternative Tourism: the Thin End of the Wedge. dalam Smith, V L and Eadington W R (eds). Philadelphia: Tourism Alternatives University of Pennsylvania Press.

Cetinel, F., dan Yolal, M. (2009). "Public Policy and Sustainable Tourism in Turkey". Tourismos: An International Multidiciplinary Journal of Tourism, 4(3), 35-50. [diakses 19 september 2019]. tersedia pada: http:/mpra.ub.uni-muenchen.de/25418/.

Coles, T., Zschiegner, A., dan Dinan, C. 2013. "Climate Change Mitigation Policy and the Tourism Sector: Perspectives from the SouthWest of England",.Journal of Policy Research in Tourism, Leisure and Events. 5(1), 1-27. [diakses 2 September 2019]. tersedia pada: https://doi.org/10.1080/19407963.2012.7349 91.

Dowling, R.K., dan Fennell, D.A. 2003. The Context of ecotourism Policy and Planning. dalam D.A. Fennell and R.K. Dowling (Eds.), Ecotourism Policy and Planning, UK: CABI Publishing.

DuCros, H., Bauer, T., Lo, C., dan Rui, S. 2005. "Cultural Heritage Asset in China as Sustainable Tourism Products: Case Studies of the Hutongs and the Huanghua Section of the Great Wall". Journal of Sustainable Tourism. 13(2). 171-194.[diakses 2 Sptember 2019]. tersedia pada: http:dx.doi.org/10.1080/09669580508668484

Edgel, D.L., Allen, M.D., Smith, G., dan Swanson, J.R. 2008. Tourism Policy and Planning Yesterday, Today and Tomorrow. Oxford: Elsevier.

Edson, G. 2004. "Heritage: Pride or Passion, Product or Service?". International Journal of
Heritage Studies. 10(4), 333-348. [diakses 2 September 2019]. tersedia pada: http:doi.org/10.1080/152725042000257366. Goeldner, C.R., dan Ritchie, B.J.R. 2006. Tourism, Principlec, Practices, Philoshopies. Nineth Ed. New Jersey: Willey \& Sons.

Kotler, P. 1997. Marketing for Tourism and Hospitality. New Jersey: Prentice Hall.

Lankford, J.K., dan Lankford, S.V. 2000. "Tourism and Sustainability: Can They be Partners?". Journal of World Leisure. 42, 4-10. [diakses 4 September 2019]. tersedia pada:

http:doi.org/10.1080/04419057.2000.967418 1.

McMorran. 2008. "Understanding the Heritage in Heritage Tourism: Ideological Tool or Economic Tool for a Japanese Hotspring Resort?”. Tourism Geographies. 10(3), 334. 354. [diakses 4 September 2019]. tersedia pada http:doi.org/10.1080/14616680802236329.

Page, S.J. 2007. Tourism Management: Managing for Change. UK: Elsevier.

Parimartha, I Gde. 2008. Warisan Budaya Subak Jatiluwih. Naskah Lengkap Sosialisasi/Presentasi Warisan Budaya Dunia Dan Alam Bali Menjadi Warisan Budaya Dunia. Denpasar.

Peraturan Daerah Provinsi Bali Nomor 2 Tahun 2012 tentang Kepariwisataan Budaya Bali.

Stevenson, N., Airey, D. dan Miller, G. 2008. "Tourism Policy Making: the Policymakers' Perspectives". Annals of Tourism Research. 35, 732-750. [diakses 2 September 2019]. tersedia pada: http:doi.org/10.1016/j.annals.2008.05.002.

Swarbrooke, J. 1999. Sustainable Tourism Management. Oxon: CABI Publishing.

Tosun, C. 2001. "Challenges of Sustainable Tourism Development in the Developing World: the Case of Turkey". Tourism Management. 22(3), 
289-303. [diakses 4 September 2019]. tersedia pada: http:doi.org/10.1080/

Undang-undang Republik Indonesia Nomor 10 Tahun 2009 tentang Kepariwisataan.

UNEP dan WTO. 2005. Making Tourism More sustainable, a Guide for Policy Makers. Madrid: UNEP \& WTO.

Vucetic. A. 2008. "Impact of Tourism Policy on Development of Selective Tourism". Selective Tourism. 4-17. [diakses 2 september 2019]. tersedia pada: http:doi.org/10.2139/ssrn.3166309./

Widari, D.A.D.S. 2015. Perkembangan Desa Wisata Jatiluwih Setelah Penetapan Subak Sebagai Warisan Budaya Dunia. (Tesis). Denpasar: Program Pascasarjana Universitas Udayana.

World Economic Forum 2017. The Travel \& Tourism Competitiveness Report 2017. Geneva: WEF.

WTO. 1998. Guide for Local authorities on Developing Sustainable Tourism. Madrid: WTO.

Xu, H., dan Sofield, T. 2013. "Sustainability in Chinese Development Tourism Policies". Current Issues in Tourism. 19 (3), 1337-1355. [diakses 4 September 2019]. tersedia pada: http:doi.org/10.1080/09669582.2015.107138 1.

Yamashita, Shinji. 2013. The Balinese Subak as World Cultural Heritages: In the Context of Tourism. Naskah Lengkap Kongres Kebudayaan Bali II. Denpasar.

http://www.docstoc.com/docs/.

\section{PROFIL PENULIS}

Dewa Ayu Diyah Sri Widari adalah Dosen Tetap di Akademi Pariwisata Denpasar sejak 2013, sebelumnya pernah menajdi Dosen Tetap di Sekolah Tinggi Pariwisata Sahid Jakarta. Hasil-hasil penelitian yang dipublikasikan mengenai kajian tentang pariwisata, pariwisata budaya, dan tourism hospitality.
Buku-buku yang sudah diterbitkan antara lain Desa Wisata Potensi dan Strategi Pengembangan, Social Media Strategic Influence in Choice of Tourism Destination: Case Study at Jatiluwih Tourism Village in Tabanan Regency Bai Province, dan Managing World Cultural Heritage. 